\title{
Surfaces
}

\section{DECONSTRUCTION AND THE DEATHS OF PHILOSOPHY: OF METAPHYSICS AND MOURNING FOR THE ARCHIVE}

\section{Peter Trifonas}

Volume 9, 2001

URI : https://id.erudit.org/iderudit/1065060ar

DOI : https://doi.org/10.7202/1065060ar

Aller au sommaire du numéro

Éditeur(s)

Les Presses de l’Université de Montréal

ISSN

1188-2492 (imprimé)

1200-5320 (numérique)

Découvrir la revue

Citer cet article

Trifonas, P. (2001). DECONSTRUCTION AND THE DEATHS OF PHILOSOPHY: OF METAPHYSICS AND MOURNING FOR THE ARCHIVE. Surfaces, 9.

https://doi.org/10.7202/1065060ar
Résumé de l'article

À travers une lecture de Derrida, l'auteur pose les questions du « droit » de la naissance et de la mort de la philosophie ainsi que de l'éthique de ses enseignements. Prenant pour appui la destruction derridéenne du logocentrisme, si reste possible une réaffirmation de la " philosophie » comme moment d'interprétation d'une entreprise de recherche disciplinaire, cela n'est possible que par un questionnement responsable de ce qui est affirmé et tenu silencieux dans la tradition occidentale de la métaphysique. Comment la déconstruction peut-elle nous aider à dénouer, à démystifier, à transgresser les limites et les limitations de l'aporie de la mort de la philosophie et à résoudre la question de sa question, de son droit, de son institution, de même que de trouver qui a le droit et la responsabilité d'y répondre? 


\section{DECONSTRUCTION AND THE DEATHS OF PHILOSOPHY: OF METAPHYSICS AND MOURNING FOR THE ARCHIVE}

Peter Trifonas

Center for Social Justice and Cultural Studies in Education University of Toronto ptrifonas@oise.utoronto.ca

Surfaces vol IX $1.2(\mathrm{v} 1.0 \mathrm{a}-15.12 .2001)$ - ISSN: 1188-2492

Tout texte reste la propriété de son auteur. Néanmoins, SURFACES demande d'être citée à l'occasion de toute autre publication du texte en question.

\footnotetext{
ABSTRACT

Through a reading of Derrida, the author addresses questions concerning the "right" of philosophy's birth and death, and the ethics of its body of teaching. Taking into account Derrida's destruction of logocentrism, if any reaffirmation of "philosophy" as the interpretational moment of a disciplinary line of inquiry is to occur, it can only be through a responsible questioning of what is said and left unsaid in the Western tradition of metaphysics. How can deconstruction help us to untangle, demystify, transgress the limits and limitations of the aporia of the death of philosophy and resolve the question of its question, and of its right, its institution, as well as who has the right and responsibility to respond to it?
} 


\section{RÉSUMÉ}

À travers une lecture de Derrida, l'auteur pose les questions du " droit " de la naissance et de la mort de la philosophie ainsi que de l'éthique de ses enseignements. Prenant pour appui la destruction derridéenne du logocentrisme, si reste possible une réaffirmation de la " philosophie " comme moment d'interprétation d'une entreprise de recherche disciplinaire, cela n'est possible que par un questionnement responsable de ce qui est affirmé et tenu silencieux dans la tradition occidentale de la métaphysique. Comment la déconstruction peut-elle nous aider à dénouer, à démystifier, à transgresser les limites et les limitations de l'aporie de la mort de la philosophie et à résoudre la question de sa question, de son droit, de son institution, de même que de trouver qui a le droit et la responsabilité d'y répondre?

"That philosophy died yesterday, since Hegel or Marx, Nietzsche, or Heidegger-and philosophy should still wander toward the meaning of its death-or that it has always lived knowing itself to be dying (as is silently confessed in the shadow of the very discourse which declared philosophia perennis); that philosophy died one day, within history, or that it has always fed on its own agony, on the violent way it opens history by opposing itself to non-philosophy, which is its past and its concern, its death and wellspring; that beyond the death, or dying nature of philosophy, perhaps even because of it, thought still has a future, or even, as is said today, is still entirely to come because of what philosophy has held in store; or, more strangely still, that the future itself has a futureall of these are unanswerable questions."

-Jacques Derrida, "Violence and Metaphysics: An Essay on the Thought of Emmanuel Levinas" [ 1 ]

To mourn the death of philosophy, or metaphysics, after deconstruction resonates as premature. For the "work"or the economy of the internal emotional and psychic labor-that sustains the logic driving the motivational force of this hyperintellectualized (theoretical) act of grieving is inopportune. Its effectivity mistakenly presupposes a common and universal recognition of the end of an epistemic tradition rooted in the rise of the Occident as an archive of teaching and learning. The 
force of this mourning of philosophy mobilizes and is mobilized by a lamentation of the violence perpetrated against the Archeology of the Letter, its arkhe and telos, the beginning and the finale of the history of metaphysics. Regret for the "pure loss,"[ $\underline{\mathbf{2}}$ ] as Jacques Derrida has called it, of an ideal consignment of knowledge leaves a space (kenosis) for the possibility of an assembling or gathering (Versammlung), a coming together, of that which would mark the scene of a new beginning onto the futures of thinking with no programmable end in sight. What will therefore arise from within the irreducible anteriority of the somaticopsychic experience of "philosophy" is the ineffable opening of metaphysics itself unto the threshold of an impossible unfolding.[ $\underline{\mathbf{3}}$ ] And yet there is no sense when dealing with an unforeseeable futurity within and without the body of the textual field of the logos and to philosophize "à corps perdu,"[ $\underline{\mathbf{4}}$ ] passionately, impetuously, with desperation, Derrida would say. There can be no success in attempting to master the outside limits of knowledge and the inexhaustive multiplicity of its sub-versive domain:

Which does not amount to acknowledging that the margin maintains itself within and without. Philosophy says so too: within because philosophical discourse intends to know and to master its margin, to define the line, align the page, enveloping it in its volume. Without because the margin, its margin, its outside are empty, are outside: a negative without effect in the text or a negative working in the service of meaning, the margin relevé (aufgehoben) in the dialectics of the Book. Thus one will have said nothing, or in any event done nothing, in declaring "against" philosophy that its margin is within or without, within and without, simultaneously the inequality of its internal spacings and the regularity of its borders.[ $\underline{\mathbf{5}}$ ]

A hyper-idealized vision can only be a "natural" (read uncritical) reaction. It feeds on itself as its mad rush of looking forward to an epistemological breakthrough of infinite possibility beckons a restoration of order beyond the encyclopedia of tradition bereft of any connections to "a past" by leaving behind or ignoring the historicity of a body of thought and thinking The phthora, a fraying, untangling or wearing-away in degradation, of the spatio-temporal organization of the structurality of the archive, after all, destabilizes the dimensions of the decisive and indivisible set of points tracing the hieratic lineage of the meaning of metaphysics, the metaphysics 
of meaning, and in the process minimizes the already myopic perspective and perspicacity of those hoping to actualize those first steps of faith toward the enactment of an impossible time-a post-philosophical era.[ $\underline{6}$ ]

A word of caution, however, is worth mentioning here as it distinguishes the two horns of the dilemma of the ouverture of metaphysics and the fathomability of its Other. To conjugate the problem of the mal d'archive, once again, is cultivating the pleasure and pain of loss both as the pathology and as the madness of the repetition compulsion, though in a different manner, concerned more with the philosophical and less fixated on the altogether moribund mourning of a philosophical death. On the one hand, all expenditures made to secure a future (for) thinking after the recognition of the impermanence, or the lack, of an absolute thought must rely on the aim to "coordinate a single corpus, in a system or a synchrony"[ $\mathbf{Z}$ ] of repeatable structures, and hence to settle the foundation of a a soci-ety, its commun-ity, its laws and institutions, what it values and teaches, protects: in short, to make real the desire to consummate, once again, the hospitality of THE DOMICILE (oikia), where "we" could live and be-athome-in-being. On the other, the reconstruction of the ground of the public sphere-the cosmopolitical[ $\underline{\mathbf{8}}$ ]-is compelled to take place with and against the recesses of memory (mneme, anamnesis, hypomnema) after the work of mourning is done, though not yet finished, and provides solace in relief of what the an-archontic, anarchival, tendency toward a dismantling of the system of hierarchical order leaves us open to,[ $\underline{\mathbf{9}}$ ] the impression of a "cleanbreak," a breach or rupture, of the history of the archive, of philosophy and its teaching. The contradiction of attempting to "close-off" or put metaphysics "between brackets" (entre crochets), [ 10 ] to try to exclude it while still having to retain ipso facto the mnemonic trace of its operating principles in order to move beyond metaphysics, to OVERCOME it,[ 11 ] soon becomes evident. And so there is a false consciousness of the loss of the archive. Its self-deluding internalization of a condition of separation as a selflimiting idea supporting the turmoil that feeds the fever of a mourning for the death of philosophy is destructive, because the focus is put on the end rather than the closure of philosophy.[ 12 ] There is no sense of respect for the alterity of what may or could come after the prolonged completion of metaphysics, after the trace of repetition wrought by time and difference. What was inaugurated through the extended path of the ontological quest to counter the forgetting of Being, sought to bring about its unconcealment, aletheia, its 
unforgetting, by attempting to recall back into cultural and epistemic memory the conceptualization of the Spirit of being and its perfected essence defined after early Greek thinking as the self-presence of presence totally present to itself.[ $\underline{13}$ ] For this well-rounded circularity was the beginning and the end of philosophy. Tensions between the "unknowable weight"[ $\underline{\mathbf{1 4}}$ ] of competing desires set to fill the chaos of the apocalyptic impression of a lack of a secure ground, and hence the absence of meaning, lead to the seductive awakening of a reconstructive drive singularly bent toward facilitating a "return to order" as an escape from a state of athesis, non-positionality, limbo.[ $1 \mathbf{1 5}$ ] All of these words most certainly are synonyms for death, the non-being of Being, and the agon of its metaphysical aporia.[ 16 ] A denegation of the genealogy of "the Idea" and its ideology does not recognize, however, that the legacy of philosophy can never be fully erased from cultural memory because the imprimatura of its diachronic sign traces the borderlines of Western thought on both sides of the limit of its dividing line. The agonia of fighting against the renunciation of that which we desire to keep close to home because it is familiar (heimliche), familiarity itself-where "we" live and dwell-is saturated with the sense of the need to identify a metalanguage for externalizing the experiential loss of a stable center of meaning in the syntagmata of metaphysics and to facilitate the releasing of an excessive melacholia resulting from the (post)modern subject losing faith in its semiotico-psychic attachments to an ordered conception of life-world (Lebenswelt) "bit by bit" (Einzeldurchführung).[ 17 ]

And yet neither Derrida nor deconstruction-the one not being the same as the other-has ever acknowledged, called for, or celebrated the death of philosophy-if such a thing could indeed be "celebrated," welcomed in its popularization. Since the enclosure of metaphysics in a frame of perfect finitude places restrictions on the possibility and impossibility of engaging thinking at the outer limits of truth. And for good reason. Taking the step (not) beyond (pas au-delà) philosophy cannot likely be accomplished (from) without philosophy, if it can be accomplished at all (which is really another way of saying it cannot!). This is the aporia of passage that must be negotiated with the aid of deconstruction and its risky strategy of an ex-orbit-ant modality of reading that marks the double bind of the logic of each and any attempt to transgress or even, in some instances, arrest the progress of metaphysics, whatever this may mean to a future of thinking that has always already been in a perpetual state of closure and therefore without end. The 
route to new forms of knowledge is characterized by this ethical problem of the paradox of the lack of an outside: paradox, from its rootedness in the Greek, paradoxon, meaning a thinking beyond popular opinion (doxa) yet placed within the hyper-teleology of duty, the right (orthotes), of what can or cannot be justly glorified, deserves to be held up as an exemplary model to be emulated because it is at once a singular exception, a rare or impossible occurrence, worthy of praise, doxastic. The law of this antinomy represented by the image of the "hors-texte," whose double reading Derrida has used to identify the illusion of exteriority, the Il n'y a pas of an "out-text"/the non-presence of an "outside-ofthe-text," thus structures the inconsolability of the mournful desire to withdraw from philosophy so as to regain the essence of subject-ivity and re-claim the spirit of Being in the name of difference and its radicalization of heterogeneity: e.g., the multitudinal guises of a negative and relational locality actualized by the term "Otherness."[ $1 \mathbf{1 8}$ ] And this may seem a strange and perhaps scandalous indictment, especially to those who have struggled in good faith, yet blindly, to overturn universalism for the purpose of instating particularity, only to find that via the cultural/material space of an inscription of identity for its own sake, essentialism quickly dissipates the ethical necessity of recognizing and responding to the alterity of an Other with/in the Selfsame. The struggle to escape metaphysics, however precautionary its measures and forthrightness of purpose (good faith, ethicity, openness), will always fail outright because its closure is by definition interminable, a process of repeated repetitions, alterity, a variegation without ending or end. The incommensurability between this lack of an opening and the overzealous push to enforce a moment of finality becomes the enigmatic center of the paradox that suspends philosophy amid mirrored images of its past achievements and the impossible dreams of its future glory. But then, the ethical questioning of the trajectory of metaphysics and its hyper-genealogical aftermath beyond end and closure still persists. It proceeds: mainly, along the peras or axis of these guiding lines. Questions persist. Is the fate of philosophy doomed to pursue in vain the eschatological struggle of attempting to efface the traces of itself so as to break free from the onto-ideologico-epistemic archive of past and present knowledges? To effectively look forward to bringing about its own death in order to recreate itself anew by seeking to step beyond and by doing so step/not beyond the ground of metaphysics and its institutions? Is philosophy without philosophy possible? Desirable? Can there be a closure or/and an end of metaphysics? And would this constitute an ethical 
crisis for philosophy and its archeo-logical institution that is disseminated and regulated culturally as/in a form of teaching and learning? And what of its pedagogy? The right of its pedagogy both as form and content. Who would have the right to philosophy, to teaching and learning philosophy (the right philosophy?) and its "other heading," the right of its other heading?[ 19 ] These are no doubt difficult questions. Impossible interrogations, aporias we could assuredly call them with some confidence of the designation. In relating as they do to the history of philosophy and its institution, these questions I have posed without precaution attempt to reiterate and readdress what Derrida identifies-in the four scenarios from "Violence and Metaphysics: An Essay on the Thought of Emmanuel Levinas" cited at the beginning of this text-to be the "problems put philosophy as problems philosophy cannot resolve."[ 20 ] I must consequently disarm myself of any claims to knowledge presumptuous of "final solutions" and its liberal affectations of a teleological exodus of sorts. The force of the questioning cannot subside, however, and be absorbed in the paralyzing desire for an end-thought, an end to thought. Because it simply will not happen that I will solve the riddle of finding a way out of philosophy. It would be wiser, and surely ethical enough, to forego any such analytico-idealistic aspirations from the start, so as to prepare the path for the possibility of an affirmation arising from within or through the aporia of a nonpassage, to what may lie beyond the borders of metaphysics yet remains ensconced in the haunt of logocentrism.[ 21 ] This disarmament, curiously enough, therefore, also constitutes a necessary precaution, much needed guardrails to work against and, if possible, to exceed, Derrida would say, and thereby re-marking the dangerous boundaries of the "limits of truth" where the solid ground of reason gives way to the undecidability of the abyss, an ur-ground perhaps of an-other type, an impossible one, itself being grounded, like deconstruction, in an un-grounding of its groundedness (e.g., presence as absence or lack, neither emptiness nor a void). If I were wholly bound by a finite sense of the debt owed to the scholarly duty of attempting at all costs to reach terminal- rather than provisional-conclusions that are intended to "wrap up" research and halt discussion, I would not be predisposed to what may unexpectedly announce itself out of my rereading of another of Derrida's "educational texts" that I have temporarily suspended as I attempt to begin to engage these fundamental questions concerning the "right" of philosophy's birth and death, and the ethics of its body of teaching, also of its teaching body (corps enseignant). Still, it is not a matter of throwing all caution to the wind 
in order to make laudable pronouncements. So, I will proceed according to the caveat Derrida applies to his original presuppositions and works around, as well as under: "It may even be that these questions are not philosophical, are not philosophy's questions."[ $\underline{\mathbf{2 2}}$ ]

The thought is remarkable. Especially considering the fact that not so dissimilar questions regarding the future of metaphysics have been posed at different times during the recent history of philosophy-in a variety of registers, pitches, and tones, apocalyptic, idealist, and otherwise-by Immanuel Kant and Martin Heidegger, for example.[ 23 ] But with Derrida and the deconstruction of logocentrism, we are cognizant of the need to move to new ground now, after and out of the path of idealism and ontology, to proceed ethically with and beyond the debt and duty owed to the archeo-logical excavations of a past time. Only through a responsible questioning that rises out of what is said and left unsaid in the Western tradition of metaphysics can a reaffirmation of "philosophy" as the interpretational moment of a disciplinary line of inquiry, as the translation of an institutional framework, and as the enactment of a pedagogy potentially occur. Derrida-and I will have reiterated the following before-has consistently tried to make an epistemic shift from ontology and a classical thinking of difference to de-ontology and the affirmative ethics of différance happen, with the help of deconstruction, "an institutional practice for whom the concept of institution remains a problem."[ $2 \mathbf{4}$ ] The ethical moment of this opening of location and locality, the space and place, khorismos and khora, from which to engage and facilitate a return to questions of academic responsibility in hopes of transforming the ground of thinking and practice, is vital in its importance for what is at stake-that is, for the future of philosophy itself. Despite its wanting "to reach the point of a certain exteriority [non-closure, alterity or otherness] in relation to the totality of the age of logocentrism,"[ 25 ] deconstruction nevertheless must remain hopelessly and forever tied to the normative discourse of metaphysics. But it perseveres at taking an affirmative line of questioning with respect to the reductive formulizability of binaric thought and its hyper-simplistic, teleoidiomatic construction of the ontological difference of identity in both conceptual and empirical terms. Deconstruction, whether it wants to or not, redefines the conditional determinacy of the axiological limits to thinking that it meets and will ultimately test, so as to converge upon uncharted destinations of thinking, teaching, and learning without the confines of a readymade (etymon), contextualized map, an inalterable 
archive of "what knowledge is of most worth." Its duty to question what is held sacred, taken for granted as

TRUTH (always in boldly capital letters), even venerated, risks both all and nothing because of its open responsibility to the Other whose effects on the formation of the subject and subjectivity are incalculable. This is what Derrida's careful resigning of deconstruction to a reconsideration of these problems of philosophy that I have cited at the start of this meditation entails, implies, signifies. And, of course, dare I say it, more! As we shall see.

\section{Impossible Horizons and Other Headings: Of Democracy, Community, and the Right of Philosophy}

Tempering what we already know, perhaps always have known, with what we discovered or invented along the way to learn more about what we do not, cannot, know, we therefore must come back to the scenarios we started with to hypothesize the impossible state of a future of thinking after metaphysics. Having worked at avoiding an impatient reading to arrive at this destination, we are now ready-in light of the cosmopolitical point of view and the case of UNESCO, whose "mode of being is one that is a priori philosophical"[ 26 ]-to attempt an answer to the irreconcilable nature of the original problems from the opening of "Violence and Metaphysics" that I have used as an epigraph to get this writing under way. We will have to remind ourselves why Derrida insists "these should be the only questions today capable of founding the community, within the world, of those who are still called philosophers,"[ 27 ] which is of course, everyone and not everyone. Three points are worth further elaboration. All pertain to the critical issue of how deconstruction can help us to untangle, demystify, transgress the limits and limitations of the aporia of the death of philosophy and resolve the question of its question, and of its right, its institution, as well as who has the right and responsibility to respond to it. And why.

1. The first concerns the post-metaphysical horizons of community, both public and academic. For Derrida, it is not a simple matter of fighting against the pronouncement of the death of philosophy, even though it may be a premature burial. Or so we would like to, and have to, think. To try to resist what is posed as the end of metaphysics by mounting arguments against the finality 
of this perspective in the tradition of a "critique" or "negative determination"[ $\mathbf{2 8}$ ] that seeks its own affirmation through the violence of opposition is a wasted effort. "A philosopher is always someone for whom philosophy is not given, someone who in essence must question him or herself about the essence and destination of philosophy."[ $\mathbf{2 9}$ ] Which is to say, that the alterity of metaphysics as well as the power of its teleology is always close at hand, whether or not a transcendence of its logic ever takes place or can even happen, essentially, whether or not it is possible. Questions about the end of philosophy, and thus of the end of the historicity of history, still abound. Some pose more productive challenges to the thinking of "what, if anything, comes next?" than do others. Nevertheless, a sense of community is (oddly enough, some may say) formed around the asking of the question of the end or the death of philosophy. And this is to be expected, when the point is just to a Heideggerian overcoming ( Überwindung) of metaphysics. It is the responsibility of each individual to interrogate the limits of "a sort of axiomatic, a system of values, norms and regulating principles"[ $\underline{\mathbf{3 0}}$ ] that justify "the existence then of a properly philosophical space like UNESCO."[ 31 ] "For," Derrida warns, "such a situation and such a duty are more particular than it seems. And this can lead to fearsome practical consequences."[ $\mathbf{3 2}$ ] Such as the temptation to take a stance on one side or the other of philosophy, with or against those who desire to remember and keep alive its memory or those who choose to forget the historicity of metaphysics and forswear the finality of its death. "A community of the question about the possibility of the question"[ $\mathbf{3 3}$ ] is what Derrida calls the publicly academic space of a more productive ground of inquiry into the right to philosophy than one of either support or diffidence. It would neither reject nor embrace the Eurocentric historicity of Western thinking and its epistemico-cultural specificity that is articulated via humanism as the infinite perfectability of subjective being: the finding of the NATURE OF THE SELF and its center at the cost of losing affinity with the Other. It could not, because it is a "community of the question"-a community wrought of dissensus and not of consensus. Its potential lies in the openness of its capacity to honor and respect the value of difference, to welcome the impossibility of alterity, but not to dismiss or celebrate the ground of au courant memory for its own sake, over the unfamiliar archive of another. So, rather than dismantling the arguments of those who would like to see the demise of the right to philosophy and its Eurocentric historicity, Derrida has attempted to answer and is continuing to address the larger question 
of the death of metaphysics, its future, both directly and obliquely, because none of the answers posited are as yet satisfying enough to do justice to the persistent problem of finding a way out of philosophy. Certainly, there is an aporia at work here that seeks refuge in its displacement. And Derrida construes its difficulty in the following way:

This Eurocentric discourse forces us to ask ourselves ... whether today [referring both to the context of the lecture and to the epochal dimension of empirical time] our reflection concerning the unlimited extension and the reaffirmation of a right to philosophy should not both take into account and de-limit the assignation of philosophy to its GrecoEuropean origin or memory. At stake is neither contenting oneself with reaffirming a certain history, a certain memory of origins or of the Western history (Mediterranean or Central European, Greco-Roman-Arab or Germanic) of philosophy, nor contenting oneself with being opposed to, or opposing denial to, this memory and to these languages, but rather trying to displace the fundamental schema of this problematic by going beyond the old, tiresome, worn-out and wearisome opposition between Eurocentrism and anti-Eurocentrism. One of the conditions for getting there-and one won't get there all of a sudden in one try, it will be the effect of a long and slow historical labor that is under way-is the active becomingaware that philosophy is no longer determined by a program, an originary language or tongue whose memory it would suffice to recover so as to discover its destination, that philosophy is no more assigned to its origin or by its origin, than it is simply, spontaneously or abstractly cosmopolitical or universal. What we have lived and what we are more and more aiming for are modes of appropriation and transformation of the philosophical in nonEuropean languages and cultures. Such modes of appropriation and transformation amount neither to the classical mode of appropriation that consists in making one's own what belongs to the other (here, in interiorizing the Western memory of philosophy and assimilating it in one's own language) nor to the invention of new modes of thought which, as alien to all appropriation, would no longer 
have any relation to what one believes one recognizes under the name of philosophy.[ $\underline{\mathbf{3 4}}$ ]

No discourse "disciplined" body of knowledge claiming epistemic status, such as philosophy is and does, selfconsciously undermines its grounding conceits in both methodology and content. The principle of noncontradiction forbids it. What governs the institutional legitimacy of philosophy as a scientific endeavor is its ability to render the logic of its conclusions accountable to and for the provisions of episteme laid out by the historicity of its own doctrines of self-evident truth and the generalizability of conclusions regarding the study of empirical phenomena: what its discourse says and reveals, confirms and proves by way of an experiential facticity, about being-in-the-world. In this respect, an ethical moment attends the academic pursuit of knowledge. It occurs when thinking becomes like $a$ science, becomes "philosophy," is conceived as a universal project, inaugurates a discipline replete with models of practice to be guarded, and is not defined idiosyncratically as the general process of thought. This distinction, besides giving credence to the institutional and pedagogical formalization and formulizability of the human intellect for and within the structures of the modern university, remains highly problematic. The division between "philosophy and Denken, thinking," [ 35 ] re-enforces the ethico-epistemic specificity of academic responsibility in this manner by setting down the template for marking out the limits of the paragon of a community (to be) instituted, whereby the laws it creates ultimately support and mobilize a divining line that distinguishes those "who belong" to it from those "who do not" and, in all probability, never will. The partisanship of discipline and disciplinarity plays upon the need for philosophy to be affiliated with the historicity of a "culture." Here we must give way to caution, though, not to presume to know too much. "There are cultural aspects of philosophy," Derrida maintains, "but philosophy is not a cultural phenomenon." What does this mean, exactly, in both the narrow and broader sense of a community of shared and differing interests?

2. This brings us to the second point. To say that philosophy is a cultural phenomenon would be to universalize it, to deny "the relationship between philosophy and natural languages, European languages, "[ $\underline{\mathbf{3 6}}$ ] living and breathing languages, that are proper to and establish the propriety of philosophy as a Western invention of the consciousness of the West and the articulation of its archive. And Derrida is 
sufficiently clear about this undeniable linguistic historicity, while attempting "to avoid the opposition between two symmetrical temptations, one being to say that philosophy is universal":[ $\underline{37}$ ]

Today it's a well-known phenomenon-there is a Chinese philosophy, a Japanese philosophy, and so on and so forth. That's a contention I would resist. I think there is something specifically European, specifically Greek in philosophy to say that philosophy is something universal. . . . Philosophy is a way of thinking. It's not science. It's not thinking in general. So when I say, well, philosophy has some privileged relationship with Europe, I don't say this European-centrically but to take seriously history. That's one temptation, to say philosophy is universal.[ $\underline{\mathbf{3 8}}$ ]

The closure of philosophy does not mean a gathering together of the Greco-European reality of its roots and forcefully bringing them to an end that would, for all intents and purposes, lack any semblance of historicity and is then without a future. The breakthrough of whatis-to-come must always arise out of the resources of a past thinking that cannot be effectively renounced. The trace of Greco-European cultural memory in philosophy will neither allow itself to be eradicated nor to be abandoned at the limit of the archive of knowledge it is and represents in method, form, and content. The first "temptation" leads to the second, both contrary and complementary, one Derrida warns us about-the desire to say:

well philosophy has only one origin, a single pure origin that is its foundation, its institution, through a number of grounding concepts which are linked to Greek language, and we have to keep this in memory and constantly go back to Greece and back to this Greek origin, European, through anamnesis, through memory, to what philosophy is. This is a symmetrical temptation which I would like to avoid.[ $\underline{39}$ ]

The Eurocentric myopia of this monocultural view of the archive of Western episteme is another peril of taking sides without actualizing sufficient precautions against the irresponsibility of academic solipsism. Magnifying the question of the historicity of philosophy and of the purity of its Greek origins, the example foreshadows the necessity of moving beyond the concept of a universal 
thought and recognizing the rise of the cosmopolitical condition that Kant predicted as a moment in the infinite process of eternal becoming, or the point in history where a giant step in the progress of humanity can be seen resulting from an outgrowth of the global selfawareness and situatedness of human being. Derrida stresses the virtues of "another model"[ $\underline{\mathbf{4 0}}]$ whose approach to truth cannot be distilled quite so easily into a program of "Eurocentrism and a simple-minded antiEurocentrism.":[ $\underline{\mathbf{4 1}}]$

that is, while keeping in memory this European, Greek origin of philosophy, and the European history of philosophy, take into account that there are events, philosophical events, which cannot be reduced to this single origin, and which meant that the origin itself was not simple, that the phenomena of hybridization, of graft, or translation, was there from the beginning, so we have to analyze the different philosophical events today, in Europe and outside of Europe.[ $\underline{\mathbf{4 2}}$ ]

In essence, the attempt to make philosophy live out its future after the historicity of its Greco-European past, requires the space of an aporia "that cannot be locked into this fundamentally cultural, colonial, or neo-colonial dialect of appropriation and alienation." [ $\underline{\mathbf{4 3}}$ ] There must be more. "There are other ways for philosophy than those of appropriation as expropriation (to lose one's memory by assimilating the memory of the other, the one being opposed to the other, as if an ex-appropriation was not possible, indeed the only possible chance)."[ $\underline{\mathbf{4 4}}$ ] Derrida is right. The testimony of memory and its reaffirming of an ethical response and responsibility to the historicity of the past is important for inscribing and building the "horizon of a new community."[ $\underline{45}$ ] It is not a matter of reasonable speculation: as the "speculative moment within the academy"[ $\underline{\mathbf{4 6}}$ ] will not do justice to re-thinking the new situation of nations and states, of peoples, that must "transform their assumptions"[ $\underline{47}$ ] (Discussion 3) in relation to what we now know is the urgent necessity of "displacing some concepts which are absolutely essential to th[e] constitutions"[ $\underline{\mathbf{4 8}}$ ] of international institutions like the United Nations and UNESCO. The cosmopolitical hybridization of empirical and epistemic identity Derrida speaks of does not involve trying to erase the history of one's own memory by working (in vain) to appropriate the effects and affectivity of another archive-the archive of an "Other"-whose expropriation would be causally determined via the need for a political maneuvering or 
strategically motivated as the willful adoption of its tenets would just happen to jibe with the dominant ideology of the day. Nor does it imply making an attempt to start over without history by pursuing misguided efforts to efface the contextual and institutional specificity of subjectivity through a haphazard rejection of the philosophical grounding of one's sense of being-inthe-world. On the one hand, a re-thinking of

"Eurocentrism and anti-colonialism"[ $\underline{\mathbf{4 9}}]$ as "symptoms of a colonial and missionary culture"[ $\underline{\mathbf{5 0}}$ ] would facilitate other beginnings and other directions for the infinite progress of human being. On the other, "a concept of the cosmopolitical that would still be determined by such opposition would not only still concretely limit the development of the right to philosophy but also would not even account for what happens in philosophy."[ $\underline{\mathbf{5 1}}$ ] Do we have any chance of surpassing the hindrances and obstacles of respecting a desire to promote and protect the call for either the appropriation (expropriation) or ex-appropriation of Western metaphysics on a global and international scale?

If philosophy could ever hope to overcome the impossible dream of achieving its own end, it would be precisely from a curious rupturing of the idea of its historicity, the memory of its being-past, which, of course, could and would never happen. And we should not want an expunging of the history of philosophy to occur, if it were even possible. Metaphysics does not have to be forcefully sedated, sanitized, and subdued. Also, we do not have to issue a proclamation that would render it alive or sentence it to death. Derrida explains, "Not only are there other ways for philosophy, but philosophy, if there is any such thing, is the other way. And it has always been the other way."[ $\underline{\mathbf{5 2}}$ ] To be unequivocal, philosophy "has always been bastard, hybrid, grafted, multilinear, and polyglot."[ 53 ] The teaching body of the discipline has always known this fact to be true.[ $\underline{\mathbf{5 4}}$ ] Pedagogical systems highlighting methods of recitation and repetition in the delivery of its curriculum were designed as a defense against a mnemonic underdetermination of the totality and authenticity of philosophical archive. By this I mean the competing models and systems of the reason of Western episteme that explicate the ontico-ontological sources of human consciousness and being. What signals the "crisis of philosophy" and leads to a questioning of the value of its teaching and learning - thereby feeding the naive illusion of its untimely demise-are the meta-conditional links of possibility, to be more specific, the conditions of impossibility within its complex lineage that work to destabilize the history of philosophy and, consequently, 
open up the concept of philosophy to what is not "philosophy proper" or "proper to philosophy." It is this realization of an originary difference always already present within the writing of its archive that displaces and dislocates the authority of its power to signify and speak for the truth of itself. The violence of alterity as the immutable trace of the difference of an Other thoroughly permeates the historicity of Western knowledge. For "philosophy has never been the unfolding responsible for a unique, originary assignation linked to a unique language or to the place of a sole people. Philosophy does not have a sole memory."[ 55 ]

3. We will now consider the third point. The working within and against a tradition of canonical associations wrought by the instauration of memory and the limitations of its capacity exemplified in the act of forgetting (lethe) brings out the tensions of disassociation and dissonance that redefine the path of metaphysics. To achieve a spatial and temporal closure of "first philosophy" involves a segue to something other than philosophy, a thinking of philosophy lacking philosophy, where "we must adjust our practice of the history of philosophy, our practice of history and of philosophy, to this reality which was also a chance and which more than ever remains a chance"[ $\underline{\mathbf{5 6}}$ ] for the impossibility of realizing the headings of a philosophy yet to come. Derrida anticipates the future after metaphysics taking place along these lines of a debt and duty to the tradition of the past traced out by the limitations of memory and its openness to an expansion of the difference of itself as the khora of the Other. It is not only a matter of affirming the existence of philosophy, but of recognizing and acknowledging its natural right to determine the grounds for asking the questions about its sources, its limits (peras, linea) and its future, if only to establish the boundaries of debt and duty that would serve to prepare us for a thinking of what comes next from what came before. Derrida is quite clear on this: "Philosophy has always insisted upon this: thinking its other. Its other: that which limits it, and from which it derives its essence, its definition, its production."[ 57 ] One cannot beat the anti-metaphysical drum (tympan) too loudly and still expect to hear the echoes of a timelessness reserved the task of thinking. Indeed, it would be unwise to "philosophize with a hammer,"[ $\underline{\mathbf{5 8}}$ ] like Friedrich Nietzsche's Zarathustra, and ponder on how best to go about the mobilization of a "noisy pedagogy" that would displace the internal sound of seeming truth in the ears of those who enjoin a claim to knowledge with the light of a sagacity drawn from the premises of what is a risky (re)visioning of epistemology 
poised "to transform what one decries"[ 59 ] in metaphysics. The danger is that, as Derrida has warned, "in taking this risk, one risks nothing at all."[ 6 60 ] For what is unthought and therefore untaught always already opens the future of a history of thinking and directions of teaching that are "yet to come" (à-venir, $\mathrm{Zu}$ kunft).

\section{NOTES}

1. Jacques Derrida, "Violence and Metaphysics: An Essay on the Thought of Emmanuel Levinas," trans. Alan Bass, in Writing and Difference (Chicago: University of Chicago Press, 1978), 79.

2. See Jacques Derrida, Archive Fever: A Freudian Impression, trans. Eric Prenowitz (Chicago: University of Chicago Press, 1996).

3. See Jacques Derrida, Aporias, trans. Thomas Dutoit (Stanford: Stanford University Press, 1993); and Jacques Derrida, The Gift of Death, trans. David Wills (Chicago: University of Chicago Press, 1995).

4. Jacques Derrida, "Tympan," trans. Alan Bass, in Margins of Philosophy (Chicago: University of Chicago Press, 1982), xxiii.

5. Derrida, "Tympan," xxiv.

6. See Derrida, Aporias.

7. Derrida, Archive Fever, 3.

8. See Jacques Derrida, "Of the Humanities and the Philosophical Discipline: The Right to Philosophy from the Cosmopolitical Point of View (the Example of an International Institution)," trans. Thomas Dutoit, Surfaces Vol. IV. 310 Folio I (1994), 5-21. All page references to this text are from the Web site version of the journal: http://tornade.ere.umontreal.ca/-guendon/ Surfaces/vol4/derrida.html.

9. See Derrida, Archive Fever.

10. Jacques Derrida, "Between Brackets I," trans. Peggy Kamuf, in POINTS. . Interviews, 1974-1994, ed. Elizabeth Weber (Stanford: Stanford University Press, 1995), 5-29.

11. See Martin Heidegger, "The End of Philosophy and the Task of Thinking," trans. David Farrell Krell, in 
Martin Heiddeger: Basic Writings, ed. David Farrell Krell (San Francisco: HarperCollins Publishers, 1977), 373-392.

12. On the relationship between death, memory, mourning, and the archive of metaphysics as the cinders of fire and fever marking an opening to the trace of the Other, see Derrida, Archive Fever, and Jacques Derrida, Cinders, trans. Ned Lukacher (Lincoln \& London: University of Nebraska Press, 1987).

13. See Martin Heidegger, "The End of Philosophy."

14. Derrida, Archive Fever, 29.

15. See Jacques Derrida, Cinders; Jacques Derrida, The Post Card: From Socrates to Freud and Beyond, trans. Alan Bass (Chicago: University of Chicago Press, 1987); and most recently Jacques Derrida, Resistances of Psychoanalysis, trans. Peggy Kamuf, Pascale-Anne Brault, and Michael Naas (Stanford: Stanford University Press, 1998) for a discussion of the relationship between the death drive and the pleasure principle and how deconstruction interacts with psychoanalysis.

16. See Jacques Derrida, Of Spirit: Heidegger and the Question, trans. Geoffrey Bennington and Rachel Bowlby (Chicago: University of Chicago Press, 1989).

17. See Derrida, Aporias and Derrida, The Post Card.

18. An interesting discussion of this aspect of deconstruction can be found in (among other places) Derrida, Aporias, Derrida, "Violence and Metaphysics," and the farewell and final tribute Derrida expressed to Emmanuel Levinas. An English version of that testimonial and oration was published as Jacques Derrida, "Adieu," Philosophy Today 40, no. 3 (1996): 33-340.

19. Regarding the question of the right to philosophy see Derrida, "Of the Humanities and the Philosophical Discipline" and Jacques Derrida, Du du droit à la philosophie (Paris: Galilée, 1990).

20. Derrida, "Violence and Metaphysics," 79.

21. Refer to Derrida, Aporias.

22. Derrida, "Violence and Metaphysics," 79.

23. Peter Fenves, ed., Raising the Tone of Philosophy: Late Essays from Immanuel Kant, Transformative 
Critique by Jacques Derrida (Baltimore: Johns Hopkins University Press, 1993) contains a fine overview of the "topicality of tone" in the history of philosophy that is the cause and the precursor to the call for an end to metaphysics since Heidegger.

24. Derrida, Du droit à la philosophie, 88. (All translations from this text are my own.)

25. Jacques Derrida, Of Grammatology, trans. Gayatri Chakravorty Spivak (Baltimore: Johns Hopkins University Press, 1974), 161-162.

26. Derrida, "Of the Humanities and the Philosophical Discipline," 2.

27. Derrida, "Violence and Metaphysics," 79.

28. Derrida, "Violence and Metaphysics," 80.

29. Derrida, "Of the Humanities and the Philosophical Discipline," 2.

30. Derrida, "Of the Humanities and the Philosophical Discipline," 2.

31. Derrida, "Of the Humanities and the Philosophical Discipline," 2.

32. Derrida, "Of the Humanities and the Philosophical Discipline," 3.

33. Derrida, "Violence and Metaphysics," 80.

34. Derrida, "Of the Humanities and the Philosophical Discipline," 3.

35. Derrida, "Des humanités," 2.

36. Derrida, "Des humanités," 2.

37. Derrida, "Des humanités," 2.

38. Derrida, "Des humanités," 2.

39. Derrida, "Des humanités," 2.

40. Derrida, "Des humanités," 2.

41. Derrida, "Des humanités," 2 .

42. Derrida, "Des humanités," 2. 
43. Derrida, "Of the Humanities and the Philosophical Discipline," 4.

44. Derrida, "Of the Humanities and the Philosophical Discipline," 3.

45. Derrida, "Des humanités," 3.

46. Derrida, "Des humanités," 3.

47. Derrida, "Des humanités," 3.

48. Derrida, "Des humanités," 3.

49. Derrida, "Of the Humanities and the Philosophical Discipline," 4.

50. Derrida, "Of the Humanities and the Philosophical Discipline," 4.

51. Derrida, "Of the Humanities and the Philosophical Discipline," 4.

52. Derrida, "Of the Humanities and the Philosophical Discipline," 4.

53. Derrida, "Of the Humanities and the Philosophical Discipline," 4.

54. See Derrida, "Où commence et comment finit un corps enseignant."

55. Derrida, "Of the Humanities and the Philosophical Discipline," 4.

56. Derrida, "Of the Humanities and the Philosophical Discipline," 4.

57. Derrida, "Tympan," x.

58. Derrida, "Tympan," xiii.

59. Derrida, "Tympan, xii.

60. Derrida, "Tympan," xiii.

Accueil Surfaces | Table des matières | Recherche Surfaces Home Page | Table of Contents | Search

PUM | Livres | Revues | Publications électroniques | Vente et distribution 